\title{
流域貯留量推定のための モデルパラメータの一般化に関する研究 GENERALIZATION OF MODEL PARAMETERS FOR EVLUATING BASIN-SCALE SOIL MOISTURE CONTENT
}

\author{
臼谷友秀 $^{1} \cdot$ 中津川誠 ${ }^{2} \cdot$ 松岡直基 $^{3}$ \\ Tomohide USUTANI, Makoto NAKATSUGAWA and Naoki MATSUOKA \\ 1 正会員 博士（工学） 一般財団法人 日本気象協会 北海道支社（ $\bar{T} 064-8555$ 札幌中央区北 4 条西 23 丁目） \\ 2 正会員 博士（工学）＼cjkstart室蘭工業大学大学院工学研究科（广050-8585 室蘭市水元町 27-1） \\ 3非会員 一般財団法人 日本気象協会 北海道支社（广064-8555 札幌中央区北 4 条西 23 丁目）
}

\begin{abstract}
The evaluation of soil moisture content is important in forecasting flood and landslide disasters. The authors previously proposed a method for estimating soil moisture content on the basin scale based on a tank model; however, determining model parameters from the observed values has been a problem to be solved in generalizing the proposed method. In this study, determination of parameters from geological information was attempted. First, the rainfall, snowmelt and evapotranspiration of the Ishikari River basin were estimated. Next, a relational expression between the parameters of the basins of tributaries and the geologic surface area ratio was obtained, and the discharge of the Ishikari River basin was simulated based on the relational expression. As a result of the simulation, the method for determining parameters based on the geologic surface area ratio was thought to be useful in generalizing the evaluation method for basin-scale soil moisture content.
\end{abstract}

Key Words : basin storage capacity, tank model, water balance, coverage rations of particular geology types, multiple regression equation

\section{1. はじめに}

2011 年 8 月の紀伊半島豪雨, 2012 年 7 月の九州北部 豪雨，2013 年9月の台風第 18 号による大雨など，ここ 数年，観測史上最大を塗り替える大雨が毎年発生し，大 規模な洪水被害や土砂災害が多発している．洪水や土砂 災害の発生は降雨や融雪水が土壌へ浸透することが大き な要因であり，これらの事象を高い精度で予測する一つ の方策として，土中の貯留量を把握することが重要と考 える.

以上を背景に筆者らは，長期的な水循環から貯留量を 推定する手法を提案し，土砂災害時の貯留量の推定 ${ }^{1)}$ や, 貯留量を考慮し流出計算法の汎用性を高める取り組み ${ }^{2)}$ を進めている. この推定手法では，タンクモデルの貯留 高を貯留量とみなしていることから，モデルパラメータ を決める必要がある。したがって，この手法の適用は流 量資料の整備された地域に限定され，この点が本手法の 汎用化の課題となっている.

流量資料のない流域での流量推定に関しては，洪水予 測に向けタンクモデルのパラメータの総合化についての 報告 (小葉竹ら ${ }^{3)}$ ) や，長期流出を対象に地質や土地利 用などからモデルパラメータを設定する方法を提案した
研究 (横尾ら ${ }^{4)}$ ，C.-Y.XU⿱日一) ${ }^{5}$ ) などがある.いずれも， モデルパラメータを決める際に流域の地質情報を取り入 れ，パラメータ決定に有効であることを報告している. しかしながら，以上の先行研究は，融雪を考慮していな い点 (横尾らの研究 $\left.{ }^{4}\right)$ ，月単位の計算である点 (C.-Y. $\mathrm{XU}^{5}$ の研究）から，融雪期を含む期間において長期的な 日流量を推定するには適さない.

そこで本研究では，水収支を明確化した上で融雪期を 含さ長期の流量再現を目指し，地質区分の面積率（流域 面積に占める任意の地質区分の面積の割合）に基づいて モデルパラメータの設定を試み，積雪地域に位置する石 狩川の流量を再現した，具体的には，次の手順で検討を 進めた。

1）点在する気象データからメッシュデータを作成し, 石狩川全域の水文諸量（降雨，降雪，積雪，融雪， 蒸発散）をメッシュ単位で推定した.

2）これらを入力として，石狩川の主な支川流域のタン クモデルのパラメータを調整の上, 流量を再現した.

3）流域間で值に大きな差のみられたパラメータを取り 上げ，パラメータと地質区分の面積率との関係に基 づいてパラメータを算定する重回帰式を導いた。 


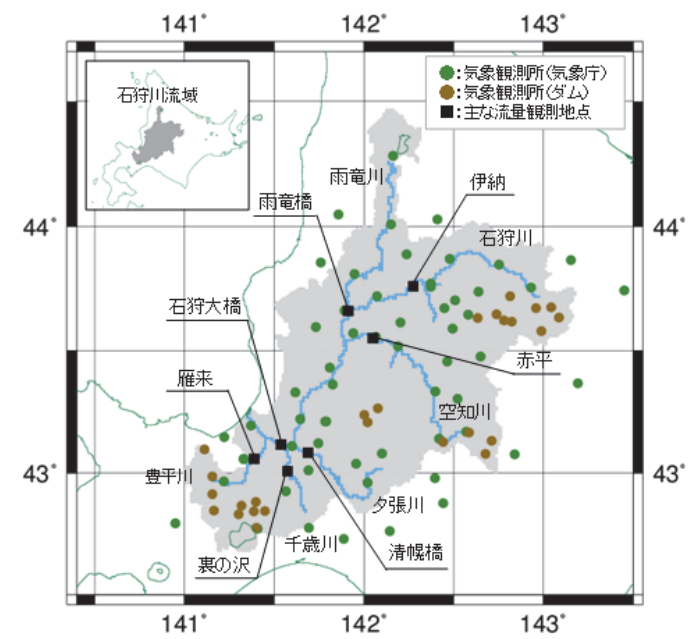

図-1 石狩川流域.

\begin{tabular}{|c|c|c|}
\hline 項目 & 要 素 & 備 \\
\hline \multirow[t]{4}{*}{ 気象 } & $\begin{array}{l}\text { 気温, 旦照時 } \\
\text { 間, 風速 }\end{array}$ & 50 地点 \\
\hline & 湿度, 日射量 & 9 地点 \\
\hline & 降水量 & 84 地点 \\
\hline & 積雪深 & 40 地点 \\
\hline 流量 & 流量 & 7 地点 (対象流域) \\
\hline \multirow[t]{4}{*}{ 地形 } & $\begin{array}{c}\text { 標高, 地被, 河 } \\
\text { 道網 }\end{array}$ & $\begin{array}{l}\text { 石狩川ランドスケープ情報 } \\
\text { (1km メッシュ) }\end{array}$ \\
\hline & $\begin{array}{l}\text { 傾斜量 (東西, } \\
\text { 南北方向) }\end{array}$ & $\begin{array}{l}\text { 国土数值情報（250m メッ } \\
\text { シュ） }\end{array}$ \\
\hline & LAI & 石井ら ${ }^{7} の$ 解析結果 \\
\hline & 地質 & 国土数值情報（G05-54M） \\
\hline
\end{tabular}

4）重回帰式によって決めたパラメータを用いて流量を 再現し，流域に適合したパラメータを用いた場合と 比較した.

以上の結果，地質区分の面積率を利用したパラメータ 設定はタンクモデルの調整に有効な手段であり，流量資 料のない流域での流量や貯留量の推定に役立つものと考 えられた。

\section{2. 対象流域と基礎データ}

解析流域は，図-1 に示寸石狩川流域である。石狩川 は，北海道中央部の大雪山系石狩岳（標高 $1,967 \mathrm{~m}$ ）に 源を発し，雨竜川，空知川などの主要支川を含む大小約 70 の河川と合流しながら石狩平野を流下し日本海に注 ぐ．流路長は $268 \mathrm{~km}$ (全国第 3 位)，流域面積は 14,327 $\mathrm{km}^{2}$ (全国第 2 位) であり，国内有数の規模を誇る河川 である. 流域は標高 $1,000 \mathrm{~m}$ 以上の山岳が石狩平野を囲 み, 平野の標高は $50 \mathrm{~m}$ 以下で比高差が大きくなってい る.

解析に用いた基礎データを表-1 に示寸. 気象データ は，流域内および流域周辺の気象庁所管の観測所（気象 官署，アメダス）を基本とした．ただし，山間部は観測 地点が少ないことから，ダムで取得されている気象デー 夕も用いた。収集期間は 1999 年 10 月〜2010 年 12 月の

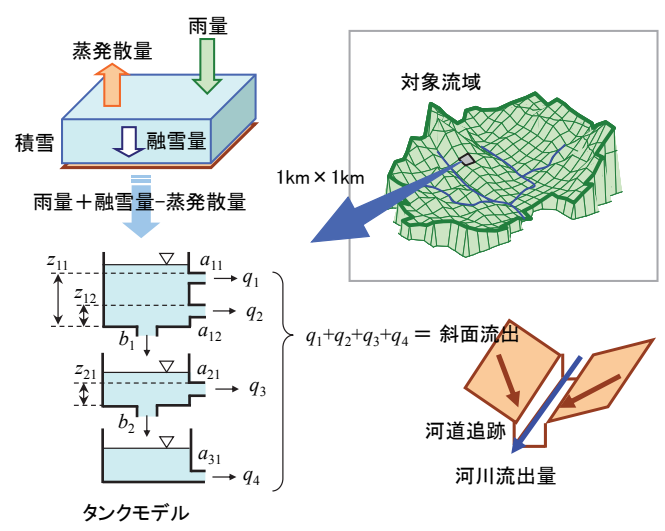

図-2 水循環計算の模式図.

約 11 年間とし，日単位のデータを対象にした。流量デ 一タは, 図-1 の印で示した 7 地点の日平均流量を収 集した。地形に関するデータには，主に石狩川流域ラン ドスケープ情報のを用いた．ただし，斜面の傾斜量は国 土数值情報（250m メッシュ）の標高を用いて $1 \mathrm{~km}$ 毎 に求めたものを用い, LAI は石井ら ${ }^{7} の$ 解析結果, 地質 には国土数值情報（G05-54M）を基礎データとした.

\section{3. 貯留量の推定手法と適合性}

\section{（1）貯留量の推定手法}

貯留量の推定に当たっては，長期的な水収支が担保さ れることが重要であり，積雪期間を含む場合には，雪に 関するプロセスも考慮しなければならない. さらに，水 文諸量には空間的な偏りがあることから，メッシュ単位 での計算が必要となる. 本研究では, 以上の観点で構築 された流域水循環モデル ${ }^{8)}$ を用いた（図-2）。

このモデルは, まず, Kriging 法や距離の逆数を重み とした方法によって点在する気象データを空間内挿し， 約 $1 \mathrm{~km}$ 四方のメッシュデータを作成する.この気象条 件に基づいて, 積雪量や融雪量, 蒸発散量といった水文 諸量をメッシュ単位で推定する．推定に用いられる手法 は，近藤ら ${ }^{9}$ の提案する 2 層モデルを基本に，積雪・融 雪過程が付加されたモデルである (口澤ら $\left.{ }^{10}\right)$ )。 以上に より, 気象データから約 $1 \mathrm{~km}$ 四方のメッシュ毎に水文 諸量 (降雨, 降雪, 積雪, 融雪, 蒸発散量) が推定され る. なお，計算は日単位で行われる。

次に, 雨量, 融雪量, 蒸発散量をタンクモデルで構成 した流出モデルに入力し，流出量を算出する.メッシュ の斜面流出量はタンクモデルを用いて計算し, kinematic wave 式を用いて任意の地点まで河道追跡を行う，以上 の計算によって河川の流量が算出される. 同時に, タン クの貯留高も計算過程で得られる. 本研究では, この夕 ンクの貯留高を各メッシュにおける貯留量とみなしてい る.

\section{（2）流域水収支の検証}

以上の手法で推定した水文諸量により，流域の水収支 


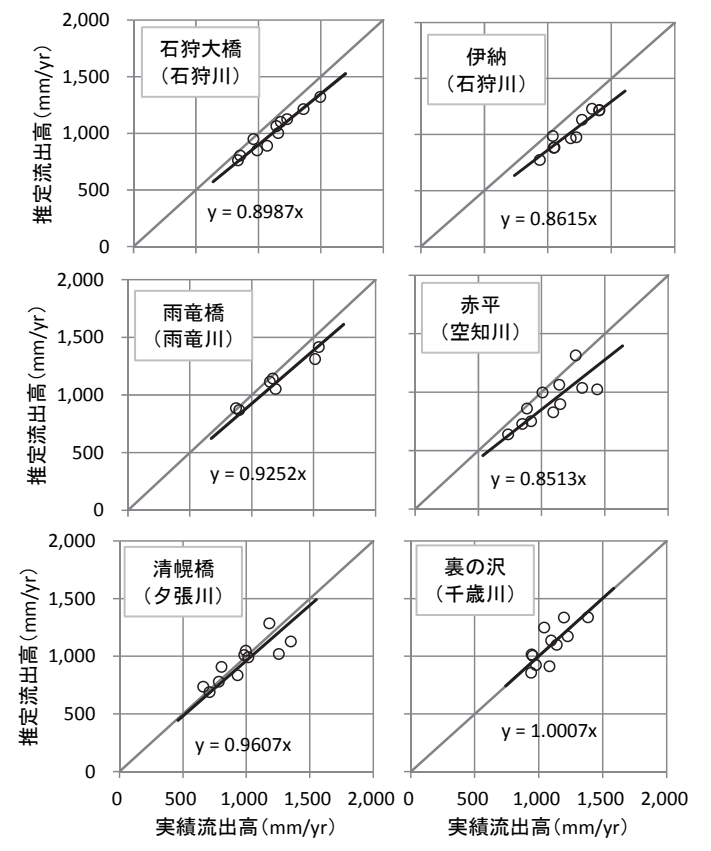

図-3＼cjkstart実績流出高と推定流出高の対応.

を確認した．ここでは，次式によって各年の 1 月〜 12 月の雨量, 融雪量, 蒸発散量から流出高を求め, この流 出高と実績流出高を比較した.

$$
Q=R+M-E-\Delta S
$$

ここで, $Q:$ 流出高 $(\mathrm{mm} / \mathrm{yr}), R$ : 雨量 $(\mathrm{mm} / \mathrm{yr}), M$ : 融雪量 $(\mathrm{mm} / \mathrm{yr}), E$ : 蒸発散量 $(\mathrm{mm} / \mathrm{yr}), \Delta S$ : 貯留量 の変化量 $(\mathrm{mm} / \mathrm{yr})$. なお, 長期的な水収支を対象とす ることから $\Delta S=0$ とした.

図-3 は，石狩川の主な流量観測地点における実績流 出高と式（1）で求めた推定流出高との関係である. 図 中, 灰色の実線は傾き $45^{\circ}$ の直線, 黒色の実線はプロ ットした点の回帰直線である.これらの図によると，推 定流出量は実績流出量に比べてやや少ない.この原因は, 地点雨量を空間内挿寸る際，山地の雨量を少なく見積つ ているためと考えられる. しかしながら，いずれの流域 とも傾き $45^{\circ}$ の直線に点が並んでおり, 推定した雨量, 融雪量, 蒸発散量は水収支の観点で概水良好な推定值で あることを示している。

表-2 は, 2000 年〜2010 年の 11 年にわたって平均し た年間の雨量, 融雪量, 蒸発散量, 流出高の推定值と実 績值である．表の右列には，推定流出高と実績流出高の 比を記載した. この表によると流出高の計算值と実績值 の比は $0.86 \sim 1.03$ の範囲にあり, 水収支的に満足し得る 水文諸量の推定がなされていると考える.

\section{（3）河川流量の検証}

以上で得られたメッシュ毎の雨量, 融雪量, 蒸発散量 を入力值として，石狩川の主な観測地点の流量を再現し た. 対象地点は, 石狩大橋（石狩川，流域面積：12,697 $\mathrm{km}^{2}$ ), 伊納 (石狩川, 流域面積 : 3,379 $\mathrm{km}^{2}$ ), 雨竜橋
表-2 年間流出高の推定精度. 2000 年 2010 年の平均.

\begin{tabular}{|c|c|c|c|c|c|c|}
\hline $\begin{array}{l}\text { 地点 } \\
\text { (河川) }\end{array}$ & $\begin{array}{c}\text { 雨量 } \\
R \\
(\mathrm{~mm} / \mathrm{yr}) \\
\end{array}$ & $\begin{array}{c}\text { 融雪量 } \\
M \\
(\mathrm{~mm} / \mathrm{yr})\end{array}$ & $\begin{array}{c}\text { 蒸発散量 } \\
E \\
(\mathrm{~mm} / \mathrm{yr})\end{array}$ & $\begin{array}{c}\text { 計算流出高 } \\
Q_{\text {cal }}=R+M-E \\
\quad(\mathrm{~mm} / \mathrm{yr})\end{array}$ & $\begin{array}{c}\text { 実績流出高 } \\
Q_{\mathrm{obs}} \\
(\mathrm{mm} / \mathrm{yr})\end{array}$ & $\begin{array}{c}\text { 比 } \\
Q_{\text {cal }} \\
/ Q_{\text {obs }}\end{array}$ \\
\hline $\begin{array}{l}\text { 石狩大橋 } \\
\text { (石狩川) }\end{array}$ & 860 & 659 & 512 & 1,007 & 1,118 & 0.90 \\
\hline $\begin{array}{c}\text { 伊納 } \\
\text { (石狩川) }\end{array}$ & 841 & 735 & 515 & 1,061 & 1,192 & 0.86 \\
\hline $\begin{array}{c}\text { 雨竜橋 } \\
\text { (雨竜川) }\end{array}$ & 796 & 800 & 510 & 1,086 & 1,191 & 0.93 \\
\hline $\begin{array}{c}\text { 赤平 } \\
\text { (空知川) }\end{array}$ & 930 & 570 & 554 & 946 & 971 & 0.97 \\
\hline $\begin{array}{c}\text { 清幌橋 } \\
\text { (夕張川) }\end{array}$ & 930 & 570 & 554 & 946 & 971 & 0.97 \\
\hline $\begin{array}{l}\text { 裏の沢 } \\
\text { (千歳川) }\end{array}$ & 965 & 514 & 386 & 1,093 & 1,091 & 1.00 \\
\hline $\begin{array}{c}\text { 雁来 } \\
\text { (豊平川) }\end{array}$ & 1,028 & 841 & 524 & 1,345 & 1,310 & 1.03 \\
\hline
\end{tabular}

表-3 各流域のタンクモデルのパラメータ.

\begin{tabular}{cccccccc}
\hline $\begin{array}{c}\text { パラ } \\
\text { メータ }\end{array}$ & $\begin{array}{c}\text { 伊納 } \\
\text { (石狩川) }\end{array}$ & $\begin{array}{c}\text { 雨童橋 } \\
\text { (雨竜川) }\end{array}$ & $\begin{array}{c}\text { 赤平 } \\
\text { (空知川) }\end{array}$ & $\begin{array}{c}\text { 清幌橋 } \\
\text { (夕張川 }\end{array}$ & $\begin{array}{c}\text { 裹の沢 } \\
\text { 千歳川) }\end{array}$ & $\begin{array}{c}\text { 雁来 } \\
(\text { 豊平川) }\end{array}$ & 残留域 \\
\hline$a_{11}$ & 0.500 & 0.215 & 0.488 & 0.090 & 0.137 & 0.359 & 0.127 \\
$a_{12}$ & 0.140 & 0.117 & 0.140 & 0.140 & 0.080 & 0.133 & 0.080 \\
$a_{21}$ & 0.149 & 0.110 & 0.145 & 0.150 & 0.148 & 0.150 & 0.150 \\
$a_{31}$ & 0.012 & 0.009 & 0.031 & 0.012 & 0.015 & 0.063 & 0.020 \\
$b_{1}$ & 0.148 & 0.100 & 0.189 & 0.130 & 0.121 & 0.100 & 0.100 \\
$b_{2}$ & 0.296 & 0.130 & 0.400 & 0.205 & 0.315 & 0.060 & 0.238 \\
$z_{11}$ & 69.93 & 47.81 & 82.43 & 56.04 & 99.23 & 88.22 & 42.75 \\
$z_{12}$ & 5.04 & 5.15 & 11.79 & 14.39 & 15.87 & 24.20 & 5.03 \\
$z_{21}$ & 16.89 & 4.67 & 0.00 & 0.00 & 29.60 & 46.57 & 17.37 \\
\hline
\end{tabular}

(雨竜川, 流域面積 : $1,712 \mathrm{~km}^{2}$ ), 赤平 (空知川, 流域 面積: 2,531 $\mathrm{km}^{2}$ ), 清幌橋 (夕張川, 流域面積: 1,116 $\mathrm{km}^{2}$ ), 裹の沢 (千歳川, 流域面積 : $1,142 \mathrm{~km}^{2}$ ), 雁来 (豊平川, 流域面積 : $651 \mathrm{~km}^{2}$ ) の 7 流域である.

タンクモデルのパラメータは, 值の異なるパラメータ を複数与えて流量を計算し，実績流量が再現できるパラ メータの組み合わせを試行錯誤によって選び出した.こ のように決めた各流域のパラメータを表-3に示寸.

以上によって再現した流量が図-4 である. 図の横軸 は日付, 左側の縦軸は流量, 右側の縦軸は雨量と融雪量 の合計値である. 水色の面は実績流量, 黒色の実線は計 算流量を表す．図によると，出水時の計算流量が過少に なる箇所はみられるものの, 融雪に伴う増水状況や厳冬 期の流水の少ない期間の状況など，長期的な流出状況は 概ね再現していることがわかる.

以上から，本手法は，石狩川の水循環を再現している ことが確認された.

\section{4. 表層地質の面積率に基づく流出計算}

\section{（1）表層地質の面積率とパラメータの設定}

表-3 に整理した值を含め，石狩川の 11 流域における 9個のタンクモデルのパラメータを表-4にまとめた. こ の表には，筆者らがこれまで検討したダム流域のパラメ 一タ 2)も合わせて示してある. 表の下の 3 行には，各パ ラメータの最大值と最小値, また, 両者の比も記載した. これによると，パラメータの最大值と最小值の比は，小 さくても 2 倍， $a_{21}$ は 150 倍にも達している. そこで本 


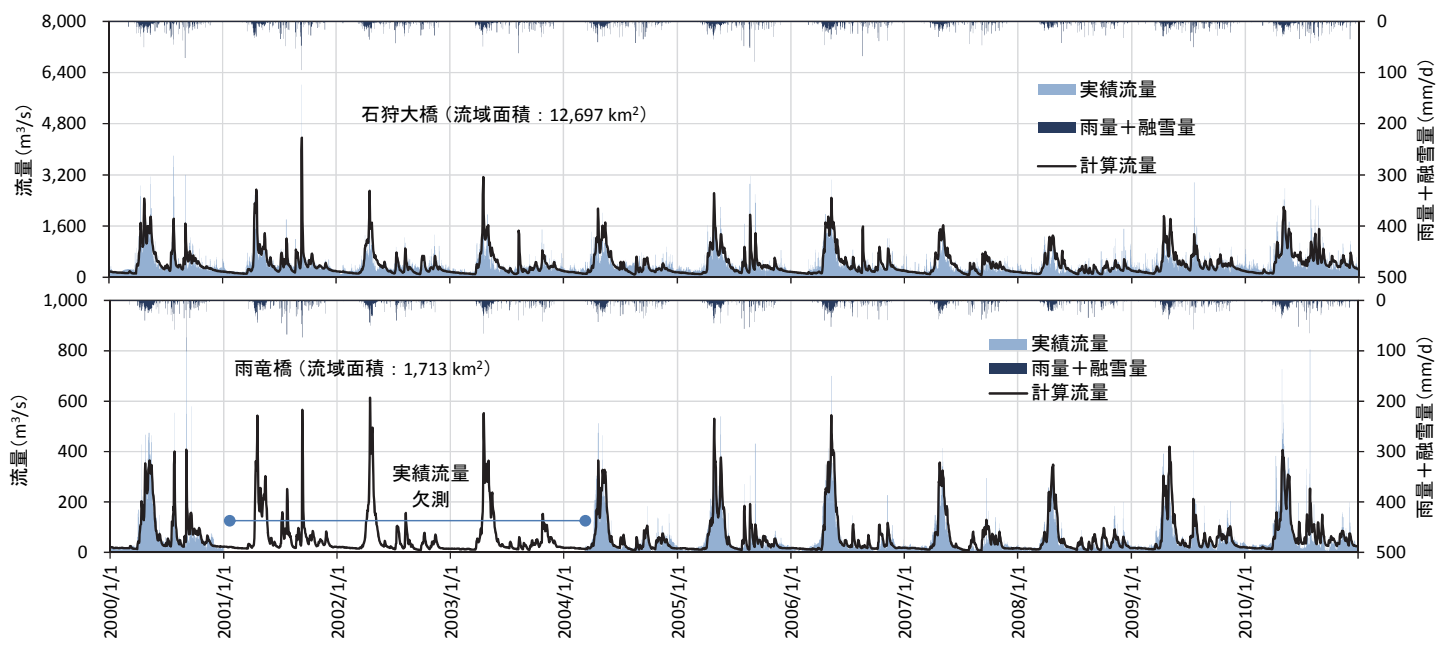

図-4 石狩川の主要観測所における流量の再現結果. 上段 : 石狩大橋, 下段 : 雨竜橋

表-4 石狩川の各流域におけるタンクモデルのパラメータと地質の面積率.

\begin{tabular}{|c|c|c|c|c|c|c|c|c|c|c|c|c|c|c|c|}
\hline \multirow[b]{2}{*}{ 流域 } & \multicolumn{2}{|c|}{ 調整パラメータ } & \multicolumn{7}{|c|}{ （流量を再現し得るよう調整したタンクモデルのパラメータ） } & \multicolumn{6}{|c|}{ 地質区分の面積率 } \\
\hline & $a_{11}$ & $a_{12}$ & $a_{21}$ & $a_{31}$ & $b_{1}$ & $b_{2}$ & $z 11$ & $z 12$ & $z 21$ & $\begin{array}{l}\text { 第三紀 } \\
\text { 火山岩 }\end{array}$ & $\begin{array}{l}\text { 第四紀 } \\
\text { 火山岩 }\end{array}$ & 花崗岩 & $\begin{array}{c}\text { 第三紀 } \\
\text { 層 }\end{array}$ & 中生層 & 古生層 \\
\hline 伊納 & 0.500 & 0.140 & 0.149 & 0.012 & 0.148 & 0.296 & 69.93 & 5.04 & 16.89 & 0.009 & 0.586 & 0.007 & 0.016 & 0.135 & 0.000 \\
\hline 雨竜橋 & 0.215 & 0.117 & 0.110 & 0.009 & 0.100 & 0.130 & 47.81 & 5.15 & 4.67 & 0.158 & 0.001 & 0.002 & 0.333 & 0.103 & 0.000 \\
\hline 赤平 & 0.488 & 0.140 & 0.145 & 0.031 & 0.189 & 0.400 & 82.43 & 11.79 & 0.00 & 0.017 & 0.232 & 0.008 & 0.097 & 0.252 & 0.000 \\
\hline 清幌橋 & 0.090 & 0.140 & 0.150 & 0.012 & 0.130 & 0.205 & 56.04 & 14.39 & 0.00 & 0.000 & 0.000 & 0.000 & 0.383 & 0.312 & 0.000 \\
\hline 裏の沢 & 0.137 & 0.080 & 0.148 & 0.015 & 0.121 & 0.315 & 99.23 & 15.87 & 29.60 & 0.122 & 0.416 & 0.000 & 0.069 & 0.000 & 0.000 \\
\hline 雁来 & 0.359 & 0.133 & 0.150 & 0.063 & 0.100 & 0.060 & 88.22 & 24.20 & 46.57 & 0.716 & 0.048 & 0.001 & 0.130 & 0.000 & 0.000 \\
\hline 大雪ダム & 0.234 & 0.104 & 0.041 & 0.100 & 0.156 & 0.054 & 89.76 & 14.36 & 65.79 & 0.006 & 0.449 & 0.029 & 0.055 & 0.362 & 0.000 \\
\hline 忠別ダム & 0.336 & 0.130 & 0.058 & 0.015 & 0.284 & 0.064 & 87.21 & 9.99 & 23.18 & 0.000 & 0.981 & 0.000 & 0.000 & 0.000 & 0.000 \\
\hline 金山ダム & 0.115 & 0.086 & 0.064 & 0.037 & 0.155 & 0.096 & 84.83 & 11.53 & 20.53 & 0.004 & 0.347 & 0.042 & 0.000 & 0.036 & 0.000 \\
\hline 桂沢ダム & 0.200 & 0.131 & 0.035 & 0.010 & 0.148 & 0.091 & 60.00 & 10.00 & 0.00 & 0.000 & 0.000 & 0.000 & 0.062 & 0.932 & 0.000 \\
\hline 漁川ダム & 0.096 & 0.067 & 0.001 & 0.027 & 0.159 & 0.226 & 55.60 & 9.77 & 9.90 & 0.267 & 0.542 & 0.000 & 0.175 & 0.000 & 0.000 \\
\hline 平均 & 0.252 & 0.115 & 0.096 & 0.030 & 0.154 & 0.176 & 74.64 & 12.01 & 19.74 & & & & & & \\
\hline 最大 & 0.500 & 0.140 & 0.150 & 0.100 & 0.284 & 0.400 & 99.227 & 24.200 & 65.793 & & & & & & \\
\hline 最小 & 0.090 & 0.067 & 0.001 & 0.009 & 0.100 & 0.054 & 47.807 & 5.041 & 0.000 & & & & & & \\
\hline 最大/最小 & 6 & 2 & 150 & 11 & 3 & 7 & 2 & 5 & - & & & & & & \\
\hline
\end{tabular}

研究では, 最大值と最小值の比が特に大きかった $a_{21}$ と, 比が 10 倍を超えていた $a_{31}$ について検討した.

なお，検討に先立ち，各パラメータの変化に対する計 算流量の感度を調べた. ここでは, 次式で算出される変 化量 Jを定義し，この值をもって評価した。

$$
J=\sqrt{\frac{1}{N} \sum_{i=1}^{N}\left(q_{\max , i}-q_{\min , i}\right)^{2}}
$$

ここで, $J$ : 変化量 $\left(\mathrm{m}^{3} / \mathrm{s}\right), N$ : 計算タイムステップ数, $q_{\max , i}:$ のタンクモデルのパラメータに最大值を与えて 計算した流量 $\left(\mathrm{m}^{3} / \mathrm{s}\right), q_{\mathrm{min}, i}$ : タンクモデルのパラメー 夕に最小值を与えて計算した流量 $\left(\mathrm{m}^{3} / \mathrm{s}\right)$.

その結果が図-5である.この図より，検討に取り上 げるパラメータ $a_{31}$ は， 9 個のパラメータの中で最も計 算流量への影響が大きいパラメータであるといえる.

検討の対象とするパラメータ $a_{21} \cdot a_{31}$ は， 2 段目およ び3段目タンクの孔の大きさであり，これらは，中間流 出成分と地下水流出成分に関わるパラメータである. 既 往研究 ${ }^{11,122,13)}$ によると, 低水時や渴水時の流量は地質と の関連性が強いことが指摘されている，そこで，地質に

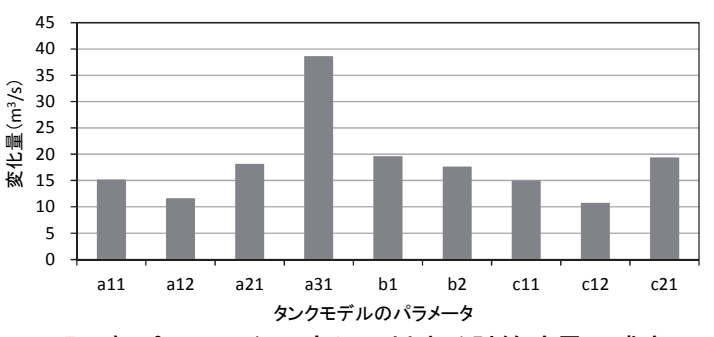

図-5 各パラメータの変化に対する計算流量の感度.

着目してパラメータ $a_{21} \cdot a_{31}$ を与えることを検討した. 地質分類は虫明ら ${ }^{11)}$ の方法に従い，国土数值情報 （G05-54M）のメッシュデータを基に，6 区分の地質に 該当するメッシュ数を流域全体のメッシュ数で除するこ とで面積率を整理した（表-4）。なお，6 区分の地質に 該当しないメッシュがあるため，各流域における面積率 の合計は 1 にはならない，また，古生層は，該当するメ ッシュがなかったことから以下の検討には用いていない. 地質区分の面積率とパラメータ $a_{21} \cdot a_{31}$ との相関係 数を図-6 に示寸.この図によると，個々の地質とパラ メータには高い相関性は見られなかった。虫明ら ${ }^{11} に$ よると，本研究で採用した 6 区分の地質における保水機 能は, 第四紀火山岩類流域が最大であり, 次に花崗岩類, 


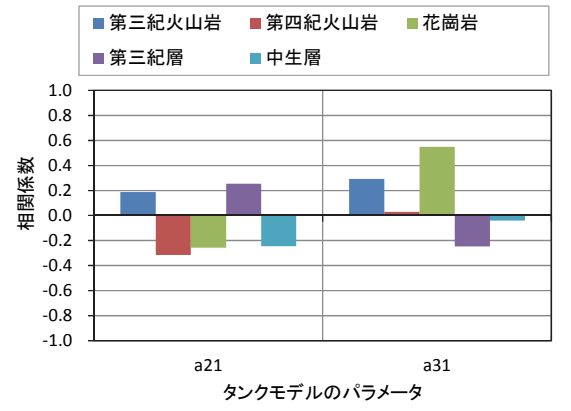

図-6 地質の面積率とパラメータ $\left(a_{21} \cdot a_{31}\right)$ の相関.

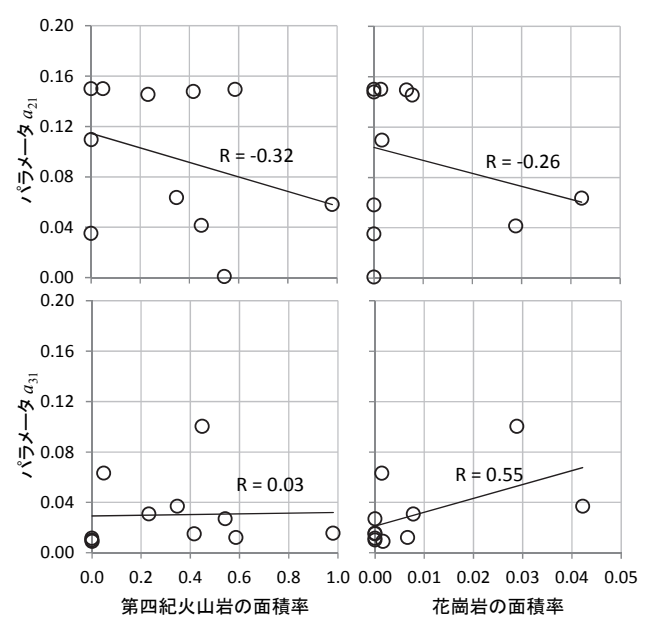

図-7第四紀火山岩および花崗岩の面積率とパラメータ $\left(a_{21} \cdot a_{31}\right)$ の相関図.

第三紀火山岩類, 中・古生層の順に小さくなることを報 告している，相関性は低いものの，これに照らし合わせ て図-6 および図-7 を見ると, 第四紀火山岩と花崗岩の パラメータ $a_{21}$ は負の相関がある. 寸なわち， 2 段目タ ンクからの流出量が減少し 3 段目タンクへの浸透量が増 えることを意味する，一方，パラメータ $a_{31}$ では，第四 紀火山岩の相関係数はほぼ 0 , 花崗岩は正の相関がある. したがって, 花崗岩の流域では, 浸透量は増えるものの 3 段目タンクからの流出量も増えるため, 第四紀火山岩 の流域ほどタンクの貯留量は増えない.このため, 3 段 目タンクの貯留量は花崗岩より第四紀火山岩の流域が多 くなり，保水機能は第四紀火山岩が大きいといえる.こ れは，先に述べた虫明ら ${ }^{11)}$ の報告に整合する結果と解 釈できる.

表-4 に示したパラメータ $a_{21} \cdot a_{31}$ を目的変数, 地質 の面積率を説明変数として重回帰式を作成した. なお, 説明変数間の相関係数は-0.61〜0.17 の範囲にあった. 得られた回帰式は次のとおりである.

$$
\begin{gathered}
a_{21}=0.312-0.185 g_{1}-0.261 g_{2}-2.769 g_{3} \\
-0.334 g_{4}-0.240 g_{5} \\
a_{31}=-0.053+0.130 g_{1}+0.075 g_{2}+1.970 g_{3} \\
+0.106 g_{4}+0.076 g_{5}
\end{gathered}
$$

ここで， $g_{1}, g_{2}, g_{3}, g_{4}, g_{5}$ : 第三紀火山岩, 第四紀 火山岩, 花崗岩, 第三紀層, 中生層の面積率.

式 (3), 式 (4) によってタンクモデルのパラメータ
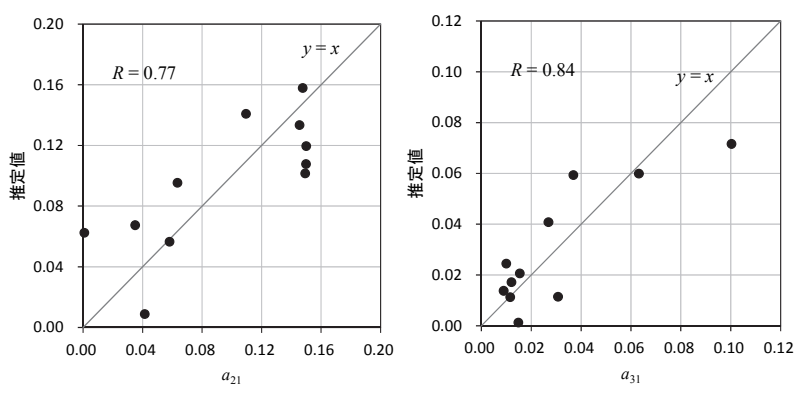

図-8＼cjkstart地質の面積率から算定値したタンクモデルのパラメー 夕. 左: $a_{21}$, 右: $a_{31}$.

を算定した結果が図-8 である. 図の横軸は表-4 の調整 パラメータ, 縦軸は式 (3) および式 (4) で算定したパ ラメータである.ここに示すように，点は散らばってい るものの，概初傾き 45 度の直線に並んでいることがわ かる.

\section{（2）重回帰式による算定パラメータを用いた流量再現}

以上で算定したパラメータ $a_{21} \cdot a_{31}$ を用い，流量を 再現した. その結果が図-9 である. なお， $a_{21} \cdot a_{31}$ を 除くパラメータは，図-6 に示したように計算流量への 影響が小さいことから，表-4 に示寸平均值を用いた。 図中，水色の面は実績流量，黒色の実線は前章で示した 計算流量, 赤色の実線は本章で検討した地質の面積率に 基づいてパラメータを与えた場合の計算流量である. 図 によると，中段に示した雨竜橋では，流量の少ない時期 において過大な推定になってはいるものの，両者のパラ メータで計算した流量には, 大きな差は見られなかった. 両者の再現計算誤差 (RMSE : 実績流量と計算流量の平 均二乗誤差の平方根）を表-5 に示すが, 誤差の増加率 は, 雨竜橋と裏の沢の 2 地点で大きいものの, 流域全体 (石狩大橋) としては，大幅な精度低下は見られなかっ た.

以上から，地質の面積率を利用したパラメータ設定は， 流出計算に有効と考えられた. ただし, 誤差の増加率が 大きかった雨竜橋と裏の沢は，地質面積率の合計が 6 割 程度と小さい（表-4）。このことが誤差の増加率を大き くする要因とも考えられ, 今後の検討課題である.

\section{5. まとめ}

流域貯留量の推定方法の一般化を目指し，モデルパラ メータの設定について検討を行った. 得られた結果を以 下にまとめる.

1）石狩川全域の水文諸量（雨量，融雪量，蒸発散量） をメッシュ単位で推定し検証した. その結果，水収 支は実態と概ね致し，妥当な水文諸量が推定でき ることを確認した。

2）この水文諸量を用い，石狩川の主な支川のタンクモ デルのパラメータを決定し，2000 年〜2010 年まで の 11 年間のハイドログラフを再現した. 


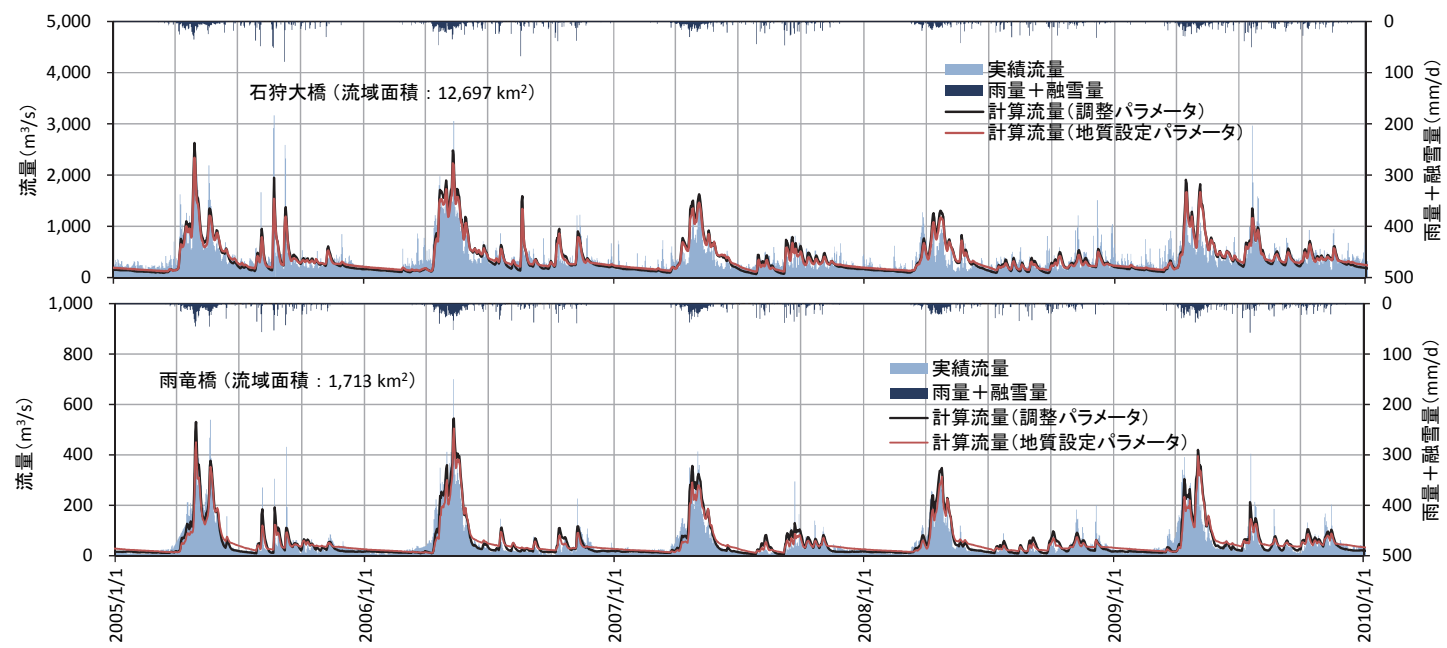

図-9 表層地質の面積率から算定したパラメータによる流量再現結果.

表-5 計算誤差 (RMSE) の増加率.

\begin{tabular}{cccc}
\hline 流域 & $\begin{array}{c}\text { 調整 } \\
\text { パラメータ } \\
e_{1}\end{array}$ & $\begin{array}{c}\text { 地質設定 } \\
\text { パラメータ } \\
e_{2}\end{array}$ & $\begin{array}{c}\text { 増加率 } \\
e_{2} / e_{1}\end{array}$ \\
\hline 石狩大橋 & 216.43 & 222.19 & 1.03 \\
伊納 & 53.16 & 54.14 & 1.02 \\
雨童橋 & 39.28 & 46.51 & 1.18 \\
赤平 & 47.06 & 47.92 & 1.02 \\
清幌橋 & 27.76 & 28.00 & 1.01 \\
裏の沢 & 17.37 & 21.77 & 1.25 \\
雁来 & 19.17 & 19.14 & 1.00 \\
\hline
\end{tabular}

3）石狩川の 11 流域におけるモデルパラメータと各流 域における地質の面積率との関係に基づき，パラメ 一タを算定する重回帰式を導いた。 ここでは，流域 間で值の差が大きい 2 個のパラメータを対象にした. 4）以上で導いた重回帰式に基づいて計算した流量と, 流域に合うよう調整したパラメータによって計算し た流量を比較した，その結果，石狩川全体（石狩大 橋）では，誤差の増大は3\%であった.

以上，地質区分の面積率は長期流出モデルのパラメー 夕設定に有効と考えられ，流量資料のない流域における 流量や貯留量を普遍的に推定し得る可能性が示された. 今後は，他の流域を対象に検証を進めるのと同時に，モ デルパラメータを決める回帰式の調整方法についても検 討を進めたい.

謝辞 : 本研究の一部は学術研究助成基金助成基金基礎研 究 (C) (課題番号 23560602) および国土交通省河川砂 防技術研究開発公募 (水防災技術分野) の助成を受けた. また，本研究を進めるにあたり，北海道開発局からデー 夕提供等で協力いただいた. ここに記して謝意を表す.

\section{参考文献}

1）臼谷友秀, 中津川誠, 松岡直基 : 融雪期の土砂災害に関 連する土㗒水分量の定量評価, 土木学会論文集 B1（水工 学) Vol.69, No.4, I_403-I_408, 2013.
2）臼谷友秀，中津川誠：流域貯留量を考慮した流出計算法 の汎用性について, 土木学会論文集 B1（水工学） Vol.68, I_463-I_468, 2012.

3）小葉竹重機, 石原安雄 : タンクモデルおよび集中面積図 を利用した流出モデルの総合化，土木学会論文報告集， 第337号，pp.129-135，1983.

4）横尾善之, 風間聡, 西村仁嗣, 沢本正樹 : 国土数值情報 に基づくタンクモデル定数の推定，水文・水資源学会誌, Vol.12, No.6, pp.481-491,1999.

5) C.-Y.XU : Estimation of Parameters of a Conceptual Water Balance Model for Ungauged Catchments, Water Resour. Manage., Vol.13, pp.353-368, 1999.

6）(財）北海道河川防災研究センター: 石狩川流域ランド スケープ情報, 1998.

7）石井孝, 梨本真, 下垣久 : 衛星データによる葉面積指数 LAI の推定，水文・水資源学会誌，Vol.12，No.3，pp.210220, 1999.

8）臼谷友秀，中津川誠，工藤啓介：石狩川流域における水 循環の定量化，北海道開発土木研究所月報，No.628,pp.1834, 2005.

9）近藤純正 : 水環境の気象学一地表面の水収支・熱収支一, 朝倉書店, 337p., 1994.

10） 口澤寿，中津川誠 : 熱・水収支を考慮した流域スケール の積雪と蒸発散量の推定, 北海道開発土木研究所月報, No.588, pp.19-38, 2002.

11）虫明功臣，高橋裕，安藤義久 : 日本の山地河川の流況に 及ぼす流域の地質の効果，土木学会論文報告集，第 309 号, pp.51-62, 1981.

12）志水俊夫 : 山地流域における渇水量と表層地質・傾斜・ 植生との関係，林試研報，No.310，pp.109-128， 1980.

13）高田賢一，中津川誠，村上泰啓 : 積雪寒冷地の流域条件 と水文・水質との関係, 水工学論文集, 第 49 巻, pp.1603-1609, 2005. 